\title{
Correspondence
}

\section{DNA: archives reveal Nobel nominations}

Recently released letters shed light on the Nobel prize nominations for the discovery of the DNA double helix 60 years ago.

On 31 December 1961, Francis Crick sent Jacques Monod, at Monod's request, a nine-page account of the discovery of the structure of DNA (see D. T. Zallen Nature 425, 15; 2003). Crick laid out what was known before work on the structure began in 1950, detailed his and James Watson's contributions and summarized work confirming that their model was correct. Crick wrote, "I hope it [the account] is not far from the sort of thing you wanted. It really is most kind of you to take all this trouble on our behalf" (source: Wellcome Library, London).

This has been taken to mean that Monod was preparing to nominate Watson and Crick for the Nobel Prize in Physiology or Medicine, which they won in 1962 with Maurice Wilkins. Watson, in his 2007 book Avoid Boring People (Knopf) wrote: "Jacques Monod [...] could not keep secret from Francis Crick that a member of the Karolinska Institutet in Stockholm had asked him to nominate us in January for the 1962 Nobel Prize in Physiology or Medicine."

We were therefore surprised not to find Monod's nomination letter among those released by the Nobel Committee for Physiology or Medicine. We found it instead in the archives of the Pasteur Institute in Paris, and, contrary to received wisdom, the nomination was for the prize in chemistry

\section{sir,}

In answer to your kind request of september 1961, the honor of

which I greatly appreciate, I would like to nominate for the Nobel

Prize in Chemistry, jointly : Drs. Francis Crick, of Cambridge Univer-

sity, J.D. Watson, of Harvard University, and M. Wilkins, of King's

College, University of London, for their discovery of the structure of

deoxyribose nucleic acid.

(see letter, pictured). In the event, the 1962 chemistry prize went to Max Perutz and John Kendrew for their determination of the structures of haemoglobin and myoglobin.

The fact that the double helix was the subject of nominations for both prizes must have presented a dilemma for the two committees. This was highlighted by a letter from Nobel laureate George Beadle (who had won the medicine prize himself in 1958) nominating Crick, Watson and Wilkins for the 1961 prize. After agreeing that the structure deserved recognition through the chemistry prize, he went on: "But I also feel — and most strongly that it is so important for biology that it should be recognized by the Prize in Physiol. \& Med. if the chemists do not do so." Perhaps, as science historian Horace Judson put it, "The Nobel committees, with a lightness of touch they had not been known to possess, had gotten together to give prizes for the two discoveries [...] made in the Cavendish Laboratory in 1953." (H. F. Judson The Eighth Day of
Creation CSHL Press, 1996).

The earliest nomination mentioning the DNA structure was from British virologist Michael Stoker, who recommended Crick and Watson for the 1960 physiology or medicine prize. This was followed by three nominations for the 1961 prize and two for the 1962 prize (see table). The first chemistry nominations (from Jacques Monod, Peter Campbell, William Stein, Harold Urey, John Cockroft and Stanford Moore) were for the 1962 prize. (Information from the Nobel Archives, The Royal Swedish Academy of Sciences.)

Crick's letter to Monod acknowledges the importance of Rosalind Franklin's X-ray data for certain features of the structure. Franklin died in 1958 and, because the Nobel prize is not awarded posthumously, she could not have been considered in 1962, nor indeed at the time of any of the earlier nominations.

Alexander Gann, Jan

A. Witkowski Cold Spring Harbor Laboratory, New York, USA. witkowsk@cshl.edu

\section{NOMINATIONS FOR THE NOBEL PRIZE IN PHYSIOLOGY OR MEDICINE}

\begin{tabular}{|c|c|c|c|}
\hline Nominator & Nomination submitted & Prize year & Nominees \\
\hline Michael Stoker & 22 January 1960 & 1960 & Francis Crick and James Watson \\
\hline George Beadle & 19 November 1960 & 1961 & Crick and Watson; also suggested Maurice Wilkins \\
\hline Albert Szent-Györgyi & 6 December 1960 & 1961 & Crick and Watson \\
\hline Gilbert Mudge & 23 February 1961 & 1961 & Crick and Watson \\
\hline Charles Stuart-Harris & 6 November 1961 & 1962 & Crick, Watson and Wilkins \\
\hline George Beadle & 7 November 1961 & 1962 & Crick and Watson; also suggested Wilkins \\
\hline
\end{tabular}

\section{DNA: twin strands solved the structure}

Today is the 60th anniversary of the publication in Nature of three papers on the structure of DNA, by James Watson and Francis Crick, and by teams led by my late father, Maurice Wilkins, and Rosalind Franklin (Nature 171, 737-738; 738-740 and 740-741; 1953). It is easy to forget that, in April 1953, the few scientists who had even heard of DNA mostly dismissed it as unimportant.

My father wrote to Watson and Crick at the time: "There is no good grousing - I think it's a very exciting notion and who the hell got it isn't what matters." I doubt that anyone connected with that letter would have believed how much "grousing" about 'winners' and 'losers' the next 60 years would bring.

The structure of the DNA double helix emerged from the twin strands of the University of Cambridge's conceptual model and King's College London's experimental rigour. Both contributions were vital to its precision and validation.

The four different figures in the 'race for DNA' shared a common concern about the effect of science, including their own, on humankind. None could have expected that their work would have such an impact. Let's hope the end result of this "very exciting notion", 60 years young, is that we'll all be the winners. George Wilkins London, UK. georgewilkins1@hotmail.co.uk 